Article

\title{
Potential Antagonistic Effects of Acrylamide Mitigation during Coffee Roasting on Furfuryl Alcohol, Furan and 5-Hydroxymethylfurfural
}

\author{
Dirk W. Lachenmeier ${ }^{1, * \mathbb{D}}$, Steffen Schwarz ${ }^{2}$, Jan Teipel ${ }^{1}{ }^{1}$, Maren Hegmanns ${ }^{1}$, \\ Thomas Kuballa ${ }^{1}$, Stephan G. Walch ${ }^{1}$ and Carmen M. Breitling-Utzmann ${ }^{3}$ \\ 1 Chemisches und Veterinäruntersuchungsamt (CVUA) Karlsruhe, Weissenburger Strasse 3, 76187 Karlsruhe, \\ Germany; jan.teipel@cvuaka.bwl.de (J.T.); maren.hegmanns@cvuaka.bwl.de (M.H.); \\ thomas.kuballa@cvuaka.bwl.de (T.K.); stephan.walch@cvuaka.bwl.de (S.G.W.) \\ 2 Coffee Consulate, Hans-Thoma-Strasse 20, 68163 Mannheim, Germany; schwarz@coffee-consulate.com \\ 3 Chemisches und Veterinäruntersuchungsamt Stuttgart, Schaflandstr. 3/2, 70736 Fellbach, Germany; \\ Carmen.Breitling-Utzmann@cvuas.bwl.de \\ * Correspondence: Lachenmeier@web.de; Tel.: +49-721-926-5434
}

Received: 31 October 2018; Accepted: 17 December 2018; Published: 21 December 2018

\begin{abstract}
The four heat-induced coffee contaminants-acrylamide, furfuryl alcohol (FA), furan and 5-hydroxymethylfurfural (HMF) - were analyzed in a collective of commercial samples as well as in Coffea arabica seeds roasted under controlled conditions from very light Scandinavian style to very dark Neapolitan style profiles. Regarding acrylamide, average contents in commercial samples were lower than in a previous study in 2002 (195 compared to $303 \mu \mathrm{g} / \mathrm{kg}$ ). The roasting experiment confirmed the inverse relationship between roasting degree and acrylamide content, i.e., the lighter the coffee, the higher the acrylamide content. However, FA, furan and HMF were inversely related to acrylamide and found in higher contents in darker roasts. Therefore, mitigation measures must consider all contaminants and not be focused isolatedly on acrylamide, specifically since FA and HMF are contained in much higher contents with lower margins of exposure compared to acrylamide.
\end{abstract}

Keywords: coffee; acrylamide; furfuryl alcohol; furan; 5-hydroxymethylfurfural; risk assessment

\section{Introduction}

Acrylamide is a heat-induced contaminant with frequent occurrence in foods and beverages [1-4]. It has been classified by the International Agency for Research on Cancer (IARC) as probably carcinogenic to humans (group 2A) [5]. The EFSA suggested that its margin of exposure indicates a concern for neoplastic effects based on animal evidence [6]. Coffee is an important topic in reduction of acrylamide, because its consumption may lead to $20-30 \%$ of total daily intake [7].

Following the first findings of acrylamide in foods and research into its formation mechanism [8,9], it was quickly discovered that coffee behaves differently from all other foods. While typically, the acrylamide content rises with color or browning degree due to its origin as a Maillard reaction product, for coffee, its content decreases from light to very dark roasts [10]. The maximum of acrylamide is formed very early in the roast and then decreases until the desired roasting degree is reached. Experimental studies have shown that the final acrylamide content purely depends on the roasting degree but not on the profile by which this degree is achieved (i.e., neither very slow nor very quick roasting methods have any influence) [10]. Currently, literature offers only speculation into the breakdown product of acrylamide during roasting or the reaction leading to its degradation [11].

Acrylamide is a product formed during coffee roasting by the Maillard reaction, a major pathway comprising the reaction between asparagine and reducing sugars $[12,13]$. The formation capacity is 
limited by the amount of asparagine [14], which is the reason for higher acrylamide contents found in Coffea canephora ("robusta") coffee due to its higher asparagine content.

Mitigation options may start with agronomy (e.g., species and variety selection, fertilization etc.) and roasting, but have also included strategies during processing such as asparaginase addition or lactic acid bacteria, none of which left the feasibility stage [15]. Careful removal of defective coffee beans is recommended, because these contain significantly higher amounts of asparagine ( $>2$ fold), which is a major precursor of acrylamide formation $[7,16]$. Storage of coffee may lead to considerable reduction, but the final brew preparation is believed to have little influence due to the excellent water-solubility of acrylamide [15]. Some authors suggested that the variation detected in commercial samples may predominantly reflect differences in storage time [17]. Supercritical fluid extraction can be applied to reduce acrylamide by up to 79\% [18]. Vacuum processing was suggested as a measure to reduce acrylamide in medium roasted coffee by $50 \%$ [19].

From all these factors, roasting was the predominant focus of previous research, and consistent findings hint that an increased roasting degree leads to a decrease in acrylamide formation [10,14,20-24].

Following several years of voluntary industry action with minimization concept [25], mitigation measures and benchmark levels for the reduction of the presence of acrylamide in food were recently implemented in an EU regulation [26]. The producers need to identify the critical roast conditions to ensure minimal acrylamide formation. They also need to ensure that the level of acrylamide in coffee is lower than the benchmark level of $400 \mu \mathrm{g} / \mathrm{kg}$.

Besides acrylamide, coffee may contain further heat-induced contaminants that were also classified by IARC. Namely, furan [27], and furfuryl alcohol (FA) [28,29] are possibly carcinogenic to humans (group 2B). For 5-hydroxymethylfurfural (HMF), some evidence of carcinogenic activity was found in animal experiments [30,31], but the compound has not yet been classified by IARC. Out of these, furan is the compound in coffee studied most intensely, including large surveys [32-34], while less research is available on furfuryl alcohol [35-38] and HMF [39].

\section{Materials and Methods}

\subsection{Analytical Methodology}

The analysis of acrylamide was conducted according to the standard method EN 16618:2015 using liquid chromatography in combination with tandem mass spectrometry (LC/MS/MS) [40]. In deviation to this standard, samples were defatted with a mixture of isohexane and butyl methyl ether. Furthermore solid-phase extraction (SPE) was only used for clean-up, not for concentrating the acrylamide [11]. With this method, a limit of detection (LOD) of $10 \mu \mathrm{g} / \mathrm{kg}$, and a limit of quantification (LOQ) of $30 \mu \mathrm{g} / \mathrm{kg}$ can be achieved. A repeatability relative standard deviation (RSDr) of $6 \%$ was determined within our laboratory. The method was applied successfully in several proficiency tests.

Analysis of furan was conducted using headspace-GC-MS and quantification with internal standard (furan- $\mathrm{d}_{4}$ ) as previously described [41]. A multipoint calibration $(0.65-12.94 \mathrm{mg} / \mathrm{kg}$ ) was used for quantification in SIM-Mode on a GC 7890B with MSD 5977B (Agilent Technologies, Waldbronn, BW, Germany) instead of the previously used standard addition. With this method, a LOD of $0.36 \mathrm{mg} / \mathrm{kg}$ and a LOQ of $1.2 \mathrm{mg} / \mathrm{kg}$ was achieved ( $0.5 \mathrm{~g}$ coffee sample weight). A RSDr of $3.5 \%$ was determined within our laboratory.

Analysis of furfuryl alcohol (FA) and 5-hydroxymethylfurfural (HMF) was accomplished using nuclear magnetic resonance (NMR) spectroscopy as previously described [42]. The within-laboratory RSDr was $6 \%$ for FA and 8\% for HMF. LOD and LOQ were 12 and $39 \mathrm{mg} / \mathrm{kg}$ for FA and 6 and $23 \mathrm{mg} / \mathrm{kg}$ for HMF, respectively. 


\subsection{Samples and Roasting Experiments}

Samples were obtained from official sampling for food control purposes in the German federal state Baden-Württemberg from all stages of trade, mainly supermarkets and artisanal roasters. For roasting experiments, two directly imported single estate terrace coffees (Coffea arabica and canephora) were supplied by Amarella Trading (Mannheim, BW, Germany).

Twelve separate $2.4 \mathrm{~kg}$ batches of coffee beans were roasted using an FZ-94 Laboratory Roaster (CoffeeTech, Tel Aviv, Israel). Roasting was conducted using either pure Coffea arabica or pure Coffea canephora samples. The roasting profiles (e.g., regarding temperature endpoints) were based on expert roasters' experience as best suitable for the intended coffee roast type. The systematically different roast profiles were recorded and controlled using Artisan v1.5.0 (Artisan-Scope.org, Poing, BY, Germany, 2018, https: / / artisan-scope.org).

\subsection{Risk Assessment Methodology and Statistics}

Risk assessment was conducted using the margin of exposure (MOE) methodology according to the method for comparative risk assessment previously published for alcoholic beverages [3]. Statistical correlations were assessed using linear regression analysis calculated with OriginPro V7.5 (OriginLab Corporation, Northampton, MA, USA) with $R$ being the correlation coefficient and $p$ being the significance of Pearson's test for linear relation. $p$ values below 0.05 are assumed as being significant.

\section{Results}

\subsection{Results of Roasting Experiments}

Two green coffee samples (Coffea arabica and canephora) were subjected to roasting using six different profiles, namely coffee roasting (quick and slow drying), espresso roasting (quick and slow drying) as well as Scandinavian roasting (very light roasting) and Neapolitan roasting (very black roasting). The roasting profiles for the C. canephora roasting are shown in Figure 1. Profiles for C. arabica roasting were similar (data not shown).

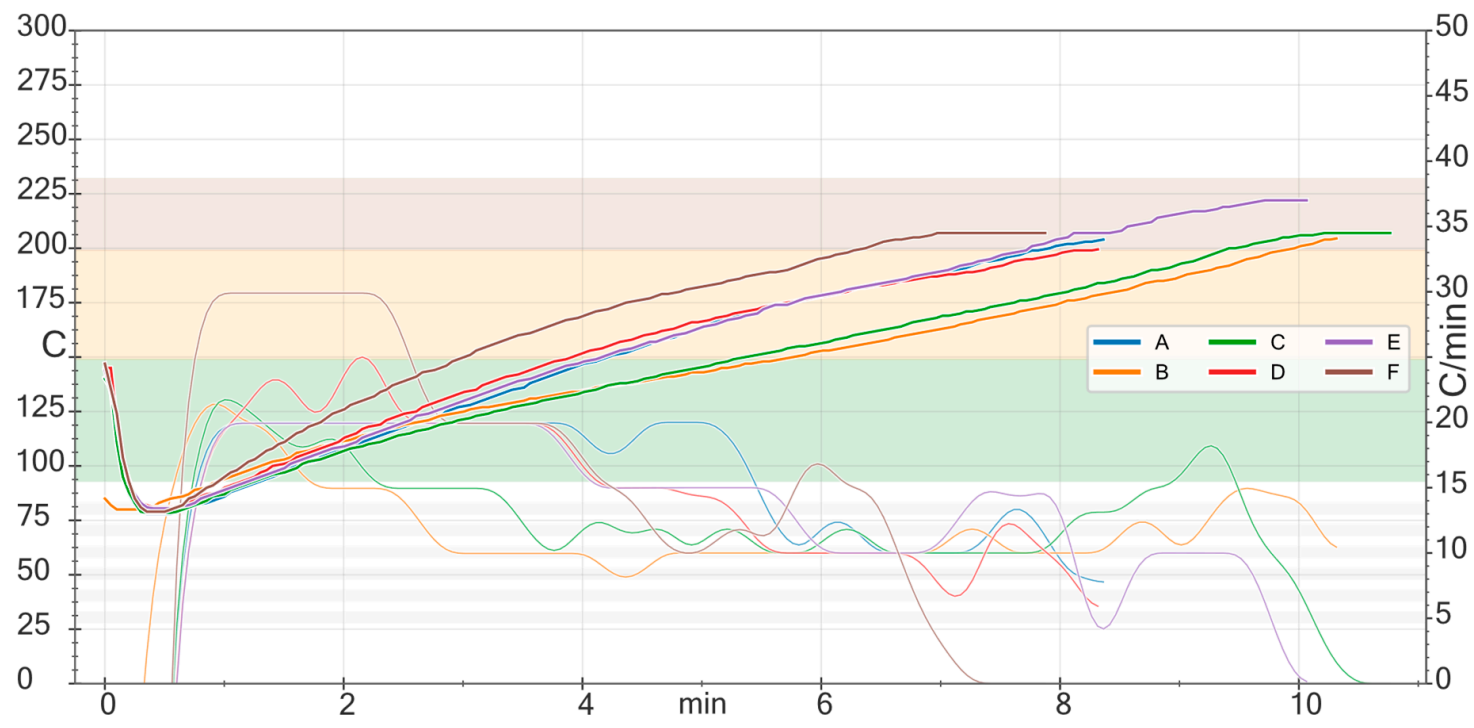

Figure 1. Profiles of experimental coffee roasting (A: Coffee quick drying; B: Coffee slow drying; C: Espresso slow drying; D: Scandinavian coffee; E: Espresso Neapolitan; F: Espresso quick drying).

Some numerical descriptors of the roasting profiles are provided in Table 1 as well as the analytical results for the samples. The individual roasting profile had a significant influence on the contents of the process contaminants. The area under the curve (AUC) is inversely related to acrylamide content $(R=-0.59 ; p=0.045 ; n=12)$, while the contents of furfuryl alcohol $(R=0.78 ; p=0.003 ; n=12)$ and 
furan $(R=0.63 ; p=0.027 ; n=12)$ are positively correlated to this roasting parameter, independent of the coffee species. Furan $(R=0.65 ; p=0.021 ; n=12)$ and furfuryl alcohol $(R=0.82 ; p=0.001 ; n=12)$ are significantly positively correlated to drop temperature. The other parameters were not significantly correlated with any analyte.

Table 1. Indicators of roasting (data for C. canephora roast; C. arabica data similar) and analytical results of roasted coffee (C. arabica/C. canephora).

\begin{tabular}{ccccccccc}
\hline Profile & $\begin{array}{c}\text { Charge }^{\mathbf{1}} \\
{\left[{ }^{\circ} \mathbf{C}\right]}\end{array}$ & $\begin{array}{c}\text { Drop } \\
{[\mathbf{m i n}]}\end{array}$ & $\begin{array}{c}\text { Drop }^{2} \\
{\left[{ }^{\circ} \mathbf{C}\right]}\end{array}$ & $\begin{array}{c}\text { AUC }^{3} \\
{\left[{ }^{\circ} \mathbf{C} \cdot \mathbf{m i n}\right]}\end{array}$ & $\begin{array}{c}\text { Acrylamide } \\
{[\boldsymbol{\mu} \mathbf{m} / \mathbf{k g}]}\end{array}$ & $\begin{array}{c}\text { Furfuryl } \\
\text { Alcohol } \\
{[\mathbf{m g} / \mathbf{k g}]}\end{array}$ & $\begin{array}{c}\text { Furan } \\
{[\mathbf{m g} / \mathbf{k g}]}\end{array}$ & $\begin{array}{c}\text { HMF } \\
{[\mathbf{m g} / \mathbf{k g}]}\end{array}$ \\
\hline Scandinavian coffee & 145 & $08: 22$ & 200 & 555 & $470 / 480$ & $70 / 93$ & $<1.2 / 2.5$ & $40 / 47$ \\
Coffee quick drying & 140 & $08: 24$ & 204 & 566 & $200 / 390$ & $124 / 94$ & $1.7 / 2.7$ & $74 / 49$ \\
Coffee slow drying & 85 & $10: 21$ & 205 & 673 & $210 / 420$ & $128 / 92$ & $1.5 / 2.6$ & $62 / 43$ \\
Espresso quick drying & 147 & $07: 55$ & 203 & 625 & $170 / 300$ & $170 / 117$ & $2.5 / 4.9$ & $66 / 47$ \\
Espresso slow drying & 140 & $10: 48$ & 207 & 762 & $150 / 290$ & $173 / 133$ & $2.6 / 5.0$ & $78 / 42$ \\
Neapolitan espresso & 145 & $10: 06$ & 222 & 796 & $130 / 250$ & $223 / 189$ & $3.6 / 7.6$ & $84 / 32$ \\
\hline
\end{tabular}

${ }^{1}$ Temperature at charge of roaster. ${ }^{2}$ Drop $=$ end of roast. ${ }^{3}$ Area under the curve (indicator how much total energy the beans have received during roasting).

There is an inverse linear statistically significant relationship between acrylamide and furfuryl alcohol $(R=-0.85 ; p<0.001 ; n=12)$, and between acrylamide and $\operatorname{HMF}(R=-0.73 ; p=0.007$; $n=12)$. None of the other pairs for contaminants were significantly correlated; however, in tendency, acrylamide and furan were also inversely correlated, while furfuryl alcohol is positively correlated with HMF and furan.

\subsection{Results of Commercial Sample Analyzes}

The full results of analysis are provided in Appendix A, Table A1. The results are summarized in Table 2. From the sub-group of samples analyzed for both acrylamide and furfuryl alcohol, an inverse linear relationship was detected $(R=-0.59 ; p=0.008 ; n=19)$. However, no correlation between HMF and acrylamide was detected, while HMF and furfuryl alcohol were positively correlated $(R=0.50$; $p=0.007 ; n=28$ ). The data set of furan analysis was too small for meaningful statistical analysis.

Despite the low number of samples, the comparison of results in Table 2 suggests that the acrylamide content in roasted coffee and in instant coffee may have decreased over the years. None of the samples has exceeded the new EU benchmark levels.

Table 2. Comparison of acrylamide analysis results from 2002 with current results (summary from Annex A, Table S1).

\begin{tabular}{|c|c|c|c|c|c|}
\hline $\begin{array}{l}\text { Category according to EU } \\
\text { Regulation } 2017 / 2158\end{array}$ & Year of Analysis & $\begin{array}{l}\text { Number of } \\
\text { Samples }\end{array}$ & $\begin{array}{l}\text { Average } \\
{[\mu \mathrm{g} / \mathrm{kg}]}\end{array}$ & $\begin{array}{l}\text { Median } \\
{[\mu \mathrm{g} / \mathrm{kg}]}\end{array}$ & $\begin{array}{c}\text { 90th } \\
\text { Percentile } \\
{[\mu \mathrm{g} / \mathrm{kg}]}\end{array}$ \\
\hline Roast coffee & 2002 (data from [11]) & 5 & 303 & 313 & 461 \\
\hline Roast coffee & 2015 & 4 & 118 & 130 & 138 \\
\hline Roast coffee & 2018 & 22 & 195 & 165 & 306 \\
\hline Instant (soluble coffee) & 2013 & 6 & 642 & 686 & 831 \\
\hline Instant (soluble coffee) & 2015 & 7 & 483 & 356 & 805 \\
\hline Instant (soluble coffee) & 2016 & 5 & 379 & 269 & 664 \\
\hline Instant (soluble coffee) & 2018 & 13 & 555 & 600 & 842 \\
\hline $\begin{array}{l}\text { Coffee substitutes exclusively } \\
\text { from cereals }\end{array}$ & 2013-2018 & 6 & 401 & 418 & 563 \\
\hline $\begin{array}{l}\text { Coffee substitutes from a } \\
\text { mixture of cereals and chicory }\end{array}$ & 2012-2018 & 16 & 587 & 525 & 805 \\
\hline
\end{tabular}




\subsection{Comparative Risk Assesment of Heat-Induced Contaminants in Coffee}

Finally, the results of comparative risk assessment using the margin of exposure methodology are shown in Table 3. The risk assessment uses survey data from the literature due to the restricted, non-representative sampling in the current study.

While the contents of acrylamide and furan are much lower than the contents of furfuryl alcohol and HMF, the toxicity thresholds of both compounds are also much lower, with acrylamide being the compound showing effects at the lowest concentration of all four compounds. Nevertheless, due to the higher exposure, HMF and furfuryl alcohol have the lowest margins of exposure. Three of the compounds, acrylamide, furfuryl alcohol and HMF, have MOEs below 10,000. Furan falls below this threshold only in worst-case scenarios (P95 exposure) and can be seen as a compound with lower risk. However, HMF is believed to operate by a non-genotoxic mechanism and hence an uncertainty factor of 100 (instead of 10,000 for genotoxic compounds) may be sufficient to exclude public health concerns.

Table 3. Risk assessment of several roasting contaminants in coffee.

\begin{tabular}{|c|c|c|c|c|}
\hline Contaminant & $\begin{array}{l}\text { Average/P95 Content } \\
\text { in Roasted Coffee }\end{array}$ & $\begin{array}{l}\text { Average/P95 Exposure for } \\
\text { Drinking } 1 \text { Cup of Coffee }{ }^{1}\end{array}$ & Toxicological Threshold ${ }^{2}$ & $\begin{array}{l}\text { Average/P95 Margin } \\
\text { of Exposure (MOE) }^{3}\end{array}$ \\
\hline Acrylamide & $249 / 543 \mu \mathrm{g} / \mathrm{kg}[6]$ & $0.05 / 0.10 \mu \mathrm{g} / \mathrm{kg}$ bw $/$ day & $\begin{array}{l}0.18 \mathrm{mg} / \mathrm{kg} \text { bw } / \text { day } \\
\text { (BDML10) [43] }\end{array}$ & $3800 / 1700$ \\
\hline Furfuryl alcohol & 251/392 mg/kg [35] & $0.05 / 0.07 \mathrm{mg} / \mathrm{kg}$ bw $/$ day & $\begin{array}{c}53 \mathrm{mg} / \mathrm{kg} \text { bw / day } \\
\text { (NOEL) [44] }\end{array}$ & $1110 / 710$ \\
\hline $\mathrm{HMF}$ & $689 / 1688 \mathrm{mg} / \mathrm{kg}$ [39] & $0.13 / 0.32 \mathrm{mg} / \mathrm{kg}$ bw $/$ day & $\begin{array}{l}79 \mathrm{mg} / \mathrm{kg} \mathrm{bw} / \text { day } \\
\text { (BMDL10) [30] }\end{array}$ & $600 / 250$ \\
\hline
\end{tabular}

${ }^{1}$ Calculated assuming $14 \mathrm{~g}$ of coffee powder per $0.2 \mathrm{~L}$ cup (according to ISO 6668 [46]) and assuming 100\% extraction yield, except for furan for which data from brewed beverage analyses were available. Average bodyweight $73.9 \mathrm{~kg}$ [47]. The data for furan were probabilistically calculated and taken from [33]. All other values were own calculations using point estimates. ${ }^{2}$ NOEL: no-observed effect level; BMDL10: benchmark dose lower confidence limit for $10 \%$ response. ${ }^{3} \mathrm{MOE}=$ Toxicological threshold/exposure. Values pessimistically rounded to significance. The higher the MOE, the lower the risk. A MOE $>10,000$ is typically interpreted as low risk for genotoxic carcinogens, while $>100$ is used for non-genotoxic compounds with thresholded effects.

\section{Discussion}

Roasting properties of coffee are basically dependent on the amount of heat transferred into the coffee beans during roasting and on the roasting time [17]. A good indicator for the achieved heat transfer rate is the area under the curve of the roasting profile. These values show a negative correlation with acrylamide during our roasting experiment, confirming the inverse relationship of roasting energy and acrylamide [10,14,20-24]. In contrast, the other contaminants under study (furfuryl alcohol, furan and HMF) appear to be positively related to the roasting energy, meaning the highest contents are typically found in the strongest roasts (espresso).

Interestingly, despite early findings that acrylamide in coffee decreases with the roasting degree, there is still considerable misinformation about this topic. Some small artisanal coffee roasters even advertise on their webpages that their "mild" roasting process with temperatures rising only up to $200{ }^{\circ} \mathrm{C}$ would result in lower acrylamide contents. The contrary being clearly the case, however.

Compared to results from our institutes published in 2002 (average acrylamide content in coffee: $303 \mu \mathrm{g} / \mathrm{kg}$, median $313 \mu \mathrm{g} / \mathrm{kg} ; 90 \%$ percentile $461 \mu \mathrm{g} / \mathrm{kg}$ ) [11], the contents found during this study were lower. In Germany, the minimization of acrylamide has been most advanced of all EU member states [25]. Manufacturers should therefore not be challenged, even if the current benchmark level should become the new legal maximum limit [25]. Our results confirm this assumption, since none of our official samples exceeded the current benchmark level.

Some authors have questioned the influence of species, e.g., Mojksja and Gielecinska [22], who found no significant difference in acrylamide contents between Arabica and Robusta coffee. Our restricted results of two pure C. canephora coffees $(260-270 \mu \mathrm{g} / \mathrm{kg})$ lie actually above the average acrylamide contents of all coffee samples $(196 \mu \mathrm{g} / \mathrm{kg})$, which is consistent with the majority of 
literature $[14,24,48]$. However, in our case a comparison is confined due to the fact that the species is unknown in most of the analyzed commercial samples. It may be speculated that the difference is caused by the lower quality of commercial C. canephora coffee with a higher degree of defective beans. However, the comparison of our high-quality single estate terrace coffees (Table 1) also points to higher levels of acrylamide in C. canephora.

There are only few studies available on the correlation of other contaminants with acrylamide. Kocadagli et al. [49] studied the kinetics of both acrylamide formation and HMF formation and found similar tendencies, meaning both acrylamide and HMF are reduced by more intense roasts. This is in contrast to our results, which detected this behavior only for acrylamide but not for HMF. An explanation may the different methodology in Kocadagli et al. [49], which did not apply a commercial coffee roaster but only an oven at $220^{\circ} \mathrm{C}$ for 5-60 min. We therefore believe that our results may have a higher relevance for commercial coffee roasting. Nevertheless, there remains some uncertainty in HMF exposure from coffee. For example, the survey reported by Arribas-Lorenzo [39] from Spain found higher HMF levels than our study with less samples. According to the German Federal Institute for Risk Assessment (BfR) evaluation, the levels of HMF in foods were suggested to exhibit no identifiable health risk for the consumer [50]. However, the BfR did not include coffee in its evaluation of HMF due to a lack of food monitoring data necessary for exposure assessment.

For other heat-induced contaminants besides acrylamide, no action has been typically taken to reduce levels and there are also no EU benchmark or maximum levels for heat-induced contaminants besides acrylamide. Therefore, focus and research activity have been mainly aimed at acrylamide in the past. The Codex Code of Practice to reduce acrylamide in foods currently does not provide guidance for coffee because to date "no commercial measures for reducing acrylamide in coffee are currently available" $[15,51]$. While this opinion is probably outdated, as various measures have shown to be effective (see introduction), our findings suggest that indeed no measures should be implemented that solely focus on acrylamide. Using a holistic risk assessment approach, all major heat-induced contaminants in coffee need to be modelled prior to pointing out any measure. Otherwise it could well mean that the benefit gained by reduction of acrylamide might be outweighed by the elevated risk of other contaminants such as furfuryl alcohol that are concomitantly increased by the applied measure. As other authors have shown $[7,20]$, holistic risk-benefit analysis would be most preferable as the mitigation of acrylamide might not only lead to increased formation of other contaminants such as furfuryl alcohol [36], but may also lead to reduced contents in beneficial compounds in coffee such as antioxidants.

Compared to other lifestyle factors such as tobacco smoking or alcohol drinking, the cancer risk from coffee (if any exists) appears to be rather low. According to IARC, epidemiological studies even suggest a lack of carcinogenicity of drinking coffee for cancer of the liver [52,53], which is the major target organ of heat-induced contaminants. Bladder cancer was the only cancer site for which an increased risk had been observed in some earlier epidemiological studies, leading to an IARC grouping as 2B in 1991 [54]. However, more recent well-conducted epidemiologic studies were unable to replicate the association with bladder cancer, and coffee consumption has been removed from the classification as a possible/probable human carcinogen [52,53].

Author Contributions: Conceptualization, D.W.L.; Methodology, D.W.L., S.S., M.H. and C.M.B.-U.; Validation, D.W.L., T.K., M.H. and C.M.B.-U.; Formal Analysis, D.W.L.; Investigation, D.W.L., M.H. and C.M.B.-U.; Resources, S.S. and S.G.W.; Data Curation, D.W.L.; Writing-Original draft preparation, D.W.L.; Writing-Review and Editing, C.M.B.-U., S.S., M.H., S.G.W., T.K., J.T.; Visualization, D.W.L., S.S.; Supervision, S.G.W.

Funding: This research received no external funding.

Acknowledgments: The laboratory teams of the NMR and the GC-MS department at CVUA Karlsruhe and beverages department at CVUA Stuttgart are thanked for excellent technical assistance. The team at Coffee Consulate is thanked for conducting the roasting experiment.

Conflicts of Interest: The authors declare no conflict of interest. 


\section{Appendix A}

Table A1. Full analytical results of samples measured between 2012-2018 for acrylamide, furfuryl alcohol and HMF.

\begin{tabular}{|c|c|c|c|c|c|c|c|}
\hline Sample ID & Sample Description & $\begin{array}{l}\text { Category according to EU } \\
\text { Regulation } 2017 / 2158\end{array}$ & Year & $\underset{(\mu \mathrm{g} / \mathrm{kg})}{\mathrm{AA}}$ & $\begin{array}{c}\text { FA } \\
(\mathrm{mg} / \mathrm{kg})\end{array}$ & $\begin{array}{l}\text { Furan } \\
(\mathrm{mg} / \mathrm{kg})\end{array}$ & $\begin{array}{c}\mathrm{HMF} \\
(\mathrm{mg} / \mathrm{kg})\end{array}$ \\
\hline 12119400 & Coffee substitute, soluble & $\begin{array}{l}\text { Coffee substitutes from a } \\
\text { mixture of cereals and chicory }\end{array}$ & 2012 & 803 & - & - & - \\
\hline $12119400-1$ & Coffee substitute, soluble & $\begin{array}{l}\text { Coffee substitutes from a } \\
\text { mixture of cereals and chicory }\end{array}$ & 2012 & 792 & - & - & - \\
\hline $12119400-2$ & Coffee substitute, soluble & $\begin{array}{l}\text { Coffee substitutes from a } \\
\text { mixture of cereals and chicory }\end{array}$ & 2012 & 806 & - & - & - \\
\hline $12119400-3$ & Coffee substitute, soluble & $\begin{array}{l}\text { Coffee substitutes from a } \\
\text { mixture of cereals and chicory }\end{array}$ & 2012 & 759 & - & - & - \\
\hline 130122855 & Coffee substitute, soluble & $\begin{array}{l}\text { Coffee substitutes from a } \\
\text { mixture of cereals and chicory }\end{array}$ & 2013 & 664 & - & - & - \\
\hline 130123291 & $100 \%$ soluble coffee & Instant (soluble) coffee & 2013 & 866 & - & - & - \\
\hline 130123334 & Coffee, soluble & Instant (soluble) coffee & 2013 & 495 & - & - & - \\
\hline 130124497 & Coffee substitute, soluble & $\begin{array}{l}\text { Coffee substitutes exclusively } \\
\text { from cereals }\end{array}$ & 2013 & 436 & - & - & - \\
\hline 130124499 & Coffee, soluble & Instant (soluble) coffee & 2013 & 744 & - & - & - \\
\hline 130127835 & $100 \%$ soluble coffee & Instant (soluble) coffee & 2013 & 796 & - & - & - \\
\hline 130128813 & Coffee, soluble & Instant (soluble) coffee & 2013 & 325 & - & - & - \\
\hline 130128818 & $100 \%$ soluble coffee & Instant (soluble) coffee & 2013 & 628 & - & - & - \\
\hline 130130022 & Coffee substitute, soluble & $\begin{array}{l}\text { Coffee substitutes from a } \\
\text { mixture of cereals and chicory }\end{array}$ & 2013 & 591 & - & - & - \\
\hline 130132127 & Coffee substitute, soluble & $\begin{array}{l}\text { Coffee substitutes from a } \\
\text { mixture of cereals and chicory }\end{array}$ & 2013 & 214 & - & - & - \\
\hline 130132150 & Coffee substitute, soluble & $\begin{array}{c}\text { Coffee substitutes exclusively } \\
\text { from cereals }\end{array}$ & 2013 & 619 & - & - & - \\
\hline 130237309 & Coffee substitute, soluble & $\begin{array}{l}\text { Coffee substitutes from a } \\
\text { mixture of cereals and chicory }\end{array}$ & 2013 & 387 & - & - & - \\
\hline 150231135 & Coffee, soluble & Instant (soluble) coffee & 2015 & 1135 & - & - & - \\
\hline 150231200 & Coffee, soluble & Instant (soluble) coffee & 2015 & 199 & - & - & - \\
\hline 150231825 & Coffee substitute, soluble & $\begin{array}{l}\text { Coffee substitutes exclusively } \\
\text { from cereals }\end{array}$ & 2015 & 508 & - & - & - \\
\hline 150231835 & Turkish coffee & Roast coffee & 2015 & 127 & - & - & - \\
\hline
\end{tabular}


Table A1. Cont.

\begin{tabular}{|c|c|c|c|c|c|c|c|}
\hline Sample ID & Sample Description & $\begin{array}{l}\text { Category according to EU } \\
\text { Regulation } 2017 / 2158\end{array}$ & Year & $\begin{array}{c}\text { AA } \\
(\mu \mathrm{g} / \mathrm{kg})\end{array}$ & $\begin{array}{c}\text { FA } \\
(\mathrm{mg} / \mathrm{kg})\end{array}$ & $\begin{array}{l}\text { Furan } \\
(\mathrm{mg} / \mathrm{kg})\end{array}$ & $\begin{array}{c}\text { HMF } \\
(\mathrm{mg} / \mathrm{kg})\end{array}$ \\
\hline 150309974 & Coffee & Roast coffee & 2015 & 70 & - & - & - \\
\hline 150309977 & Coffee, decaffeinated & Instant (soluble) coffee & 2015 & 335 & - & - & - \\
\hline 150334870 & Espresso Italiano & Roast coffee & 2015 & 132 & - & - & - \\
\hline 150334875 & Coffee, soluble & Instant (soluble) coffee & 2015 & 356 & - & - & - \\
\hline 150334880 & Coffee, soluble & Instant (soluble) coffee & 2015 & 320 & - & - & - \\
\hline 150337674 & Coffee & Roast coffee & 2015 & 141 & - & - & - \\
\hline 150337675 & Coffee, decaffeinated & Instant (soluble) coffee & 2015 & 585 & - & - & - \\
\hline 150337676 & Coffee & Instant (soluble) coffee & 2015 & 452 & - & - & - \\
\hline 160450717 & Malt coffee & $\begin{array}{l}\text { Coffee substitutes exclusively } \\
\text { from cereals }\end{array}$ & 2016 & 370 & - & - & - \\
\hline 160451307 & Coffee, soluble & Instant (soluble) coffee & 2016 & 223 & - & - & - \\
\hline 160451426 & Coffee, soluble & Instant (soluble) coffee & 2016 & 273 & - & - & - \\
\hline 160451967 & Coffee substitute, soluble & $\begin{array}{l}\text { Coffee substitutes from a } \\
\text { mixture of cereals and chicory }\end{array}$ & 2016 & 361 & - & - & - \\
\hline 160452173 & $\begin{array}{c}100 \% \text { soluble coffee, } 100 \% \\
\text { Arabica }\end{array}$ & Instant (soluble) coffee & 2016 & 269 & - & - & - \\
\hline 160452684 & Coffee substitute, soluble & $\begin{array}{l}\text { Coffee substitutes exclusively } \\
\text { from cereals }\end{array}$ & 2016 & 74 & - & - & - \\
\hline 160454844 & Coffee, soluble & Instant (soluble) coffee & 2016 & 206 & - & - & - \\
\hline 160472527 & Coffee substitute, soluble & $\begin{array}{l}\text { Coffee substitutes from a } \\
\text { mixture of cereals and chicory }\end{array}$ & 2016 & 407 & - & - & - \\
\hline 160472529 & Coffee substitute, soluble & $\begin{array}{l}\text { Coffee substitutes from a } \\
\text { mixture of cereals and chicory }\end{array}$ & 2016 & 431 & - & - & - \\
\hline 160509176 & Coffee, soluble & Instant (soluble) coffee & 2016 & 925 & - & - & - \\
\hline 160509194 & Espresso & Roast coffee & 2016 & 447 & - & - & - \\
\hline 160574673 & Coffee substitute, soluble & $\begin{array}{l}\text { Coffee substitutes from a } \\
\text { mixture of cereals and chicory }\end{array}$ & 2016 & 347 & - & - & - \\
\hline 180352602 & Coffee substitute, soluble & $\begin{array}{l}\text { Coffee substitutes from a } \\
\text { mixture of cereals and chicory }\end{array}$ & 2018 & 650 & - & - & - \\
\hline 180352683 & Coffee & Roast coffee & 2018 & 160 & 108 & 1.7 & 46 \\
\hline 180365240 & Costa Rica Arabica coffee & Roast coffee & 2018 & 170 & 108 & 2.0 & 46 \\
\hline 180379248 & India Monsooned & Roast coffee & 2018 & 150 & 74 & 5.4 & 34 \\
\hline
\end{tabular}


Table A1. Cont.

\begin{tabular}{|c|c|c|c|c|c|c|c|}
\hline Sample ID & Sample Description & $\begin{array}{l}\text { Category according to EU } \\
\text { Regulation } 2017 / 2158\end{array}$ & Year & $\begin{array}{c}\mathrm{AA} \\
(\mu \mathrm{g} / \mathrm{kg})\end{array}$ & $\begin{array}{c}\text { FA } \\
(\mathrm{mg} / \mathrm{kg})\end{array}$ & $\begin{array}{l}\text { Furan } \\
(\mathrm{mg} / \mathrm{kg})\end{array}$ & $\begin{array}{c}\text { HMF } \\
(\mathrm{mg} / \mathrm{kg})\end{array}$ \\
\hline 180398113 & Coffee & Roast coffee & 2018 & 210 & 156 & 2.3 & 52 \\
\hline 180409591 & $\begin{array}{l}\text { Arabica-Robusta-mixture, } \\
\text { coffee }\end{array}$ & Roast coffee & 2018 & 130 & 133 & 2.6 & 48 \\
\hline 180420281 & coffee, organic & Roast coffee & 2018 & 110 & 122 & - & 57 \\
\hline 180420519 & Coffee & Roast coffee & 2018 & 95 & 104 & 3.5 & 46 \\
\hline 180433746 & Coffee & Roast coffee & 2018 & 310 & 76 & - & 53 \\
\hline 180439193 & coffee, Ethiopia & Roast coffee & 2018 & 150 & - & - & - \\
\hline 180444177 & Coffee & Roast coffee & 2018 & 170 & 121 & - & 42 \\
\hline 180447473 & Coffee & Roast coffee & 2018 & 110 & 116 & - & 57 \\
\hline 180453665 & Coffee Sumatra & Roast coffee & 2018 & 120 & 119 & - & 52 \\
\hline 180468077 & Coffee & Roast coffee & 2018 & 130 & 122 & - & 51 \\
\hline 180478363 & Coffee substitute, soluble & Instant (soluble) coffee & 2018 & 730 & - & - & - \\
\hline 180481476 & Coffee substitute, soluble & Instant (soluble) coffee & 2018 & 110 & 64 & - & 40 \\
\hline 180486743 & Coffee substitute, soluble & Instant (soluble) coffee & 2018 & 670 & - & - & - \\
\hline 180486745 & Coffee substitute, soluble & Instant (soluble) coffee & 2018 & 460 & - & - & - \\
\hline 180489109 & Coffee substitute, soluble & Instant (soluble) coffee & 2018 & 420 & - & - & - \\
\hline 180489247 & Coffee substitute, soluble & Instant (soluble) coffee & 2018 & 440 & - & - & - \\
\hline 180492032 & $\begin{array}{c}100 \% \text { soluble coffee, } 100 \% \\
\text { Arabica }\end{array}$ & Instant (soluble) coffee & 2018 & 870 & - & - & - \\
\hline 180492048 & Coffee, soluble & Instant (soluble) coffee & 2018 & 660 & - & - & - \\
\hline 180494672 & Coffee, soluble & Instant (soluble) coffee & 2018 & 910 & - & - & - \\
\hline 180504580 & Coffee, soluble & Instant (soluble) coffee & 2018 & 420 & - & - & - \\
\hline 180520043 & $\begin{array}{c}100 \% \text { soluble coffee, } 100 \% \\
\text { Arabica }\end{array}$ & Instant (soluble) coffee & 2018 & 690 & - & - & - \\
\hline 180533580 & Pure Canephora coffee & Roast coffee & 2018 & 260 & 42 & - & 40 \\
\hline 180533581 & Pure Canephora coffee & Roast coffee & 2018 & 270 & 37 & - & 49 \\
\hline 180533582 & Arabica coffee & Roast coffee & 2018 & 270 & 78 & - & 46 \\
\hline 180533583 & Arabica coffee & Roast coffee & 2018 & 460 & 55 & - & 43 \\
\hline
\end{tabular}


Table A1. Cont.

\begin{tabular}{|c|c|c|c|c|c|c|c|}
\hline Sample ID & Sample Description & $\begin{array}{l}\text { Category according to EU } \\
\text { Regulation } 2017 / 2158\end{array}$ & Year & $\underset{(\mu \mathrm{g} / \mathrm{kg})}{\mathrm{AA}}$ & $\begin{array}{c}\text { FA } \\
(\mathrm{mg} / \mathrm{kg})\end{array}$ & $\begin{array}{l}\text { Furan } \\
(\mathrm{mg} / \mathrm{kg})\end{array}$ & $\begin{array}{c}\text { HMF } \\
(\mathrm{mg} / \mathrm{kg})\end{array}$ \\
\hline 180533584 & Arabica coffee & Roast coffee & 2018 & 330 & 60 & - & 35 \\
\hline 180539910 & Coffee, soluble & Instant (soluble) coffee & 2018 & 600 & - & - & - \\
\hline 180552699 & $\begin{array}{c}\text { 100\% Organic Arabica } \\
\text { coffee }\end{array}$ & Roast coffee & 2018 & 120 & - & - & - \\
\hline 180619399 & Coffee substitute, soluble & $\begin{array}{l}\text { Coffee substitutes exclusively } \\
\text { from cereals }\end{array}$ & 2018 & 400 & - & - & - \\
\hline 180619831 & Coffee, soluble & Instant (soluble) coffee & 2018 & 240 & - & - & - \\
\hline 180628887 & Espresso & Roast coffee & 2018 & 210 & - & - & - \\
\hline 180631120 & Coffee substitute, soluble & $\begin{array}{l}\text { Coffee substitutes from a } \\
\text { mixture of cereals and chicory }\end{array}$ & 2018 & 460 & - & - & - \\
\hline 180631416 & Coffee & Roast coffee & 2018 & 250 & - & - & - \\
\hline 180638375 & Espresso & Roast coffee & 2018 & 100 & 99 & - & 38 \\
\hline 180643299 & Coffee substitute, soluble & $\begin{array}{l}\text { Coffee substitutes from a } \\
\text { mixture of cereals and chicory }\end{array}$ & 2018 & 220 & - & - & - \\
\hline 180643300 & Coffee substitute, soluble & $\begin{array}{l}\text { Coffee substitutes from a } \\
\text { mixture of cereals and chicory }\end{array}$ & 2018 & 1500 & - & - & - \\
\hline
\end{tabular}

AA: Acrylamide; FA: Furfuryl alcohol; HMF: 5-Hydroxymethylfurfural;“-“: parameter not analyzed in that sample. 


\section{References}

1. Lachenmeier, D.W. Carcinogens in food: Opportunities and challenges for regulatory toxicology. Open Toxicol. J. 2009, 3, 30-34. [CrossRef]

2. Wenzl, T.; Lachenmeier, D.W.; Gökmen, V. Analysis of heat-induced contaminants (acrylamide, chloropropanols and furan) in carbohydrate-rich food. Anal. Bioanal. Chem. 2007, 389, 119-137. [CrossRef] [PubMed]

3. Lachenmeier, D.W.; Przybylski, M.C.; Rehm, J. Comparative risk assessment of carcinogens in alcoholic beverages using the margin of exposure approach. Int. J. Cancer 2012, 131, E995-E1003. [CrossRef] [PubMed]

4. Pflaum, T.; Hausler, T.; Baumung, C.; Ackermann, S.; Kuballa, T.; Rehm, J.; Lachenmeier, D.W. Carcinogenic compounds in alcoholic beverages: An update. Arch. Toxicol. 2016, 90, 2349-2367. [CrossRef] [PubMed]

5. IARC Working Group on the Evaluation of Carcinogenic Risks to Humans. Acrylamide. IARC Monogr. Eval. Carcinog. Risks Hum. 1994, 60, 389-433. [PubMed]

6. EFSA Panel on Contaminants in the Food Chain. Scientific Opinion on acrylamide in food. EFSA J. 2015, 13, 4104. [CrossRef]

7. Guenther, H.; Anklam, E.; Wenzl, T.; Stadler, R.H. Acrylamide in coffee: Review of progress in analysis, formation and level reduction. Food Addit. Contam. 2007, 24 (Suppl. 1), 60-70. [CrossRef] [PubMed]

8. Tareke, E.; Rydberg, P.; Karlsson, P.; Eriksson, S.; Tornqvist, M. Analysis of acrylamide, a carcinogen formed in heated foodstuffs. J. Agric. Food Chem. 2002, 50, 4998-5006. [CrossRef]

9. Tareke, E.; Rydberg, P.; Karlsson, P.; Eriksson, S.; Tornqvist, M. Acrylamide: A cooking carcinogen? Chem. Res. Toxicol. 2000, 13, 517-522. [CrossRef]

10. Deutscher Kaffeeverband. Jahresbericht 2004; Deutscher Kaffeeverband e.V.: Hamburg, Germany, 2005.

11. Gutsche, B.; Weisshaar, R.; Buhlert, J. Acrylamide in food-Screening results from food control in Baden-Württemberg. Dtsch. Lebensm. Rundsch. 2002, 98, 437-443.

12. Soares, C.M.D.; Alves, R.C.; Oliveira, M.B. Acrylamide in coffee: Influence of processing. In Processing and Impact on Active Components in Food; Preedy, V., Ed.; Academic Press: San Diego, CA, USA, 2015; pp. 575-582. [CrossRef]

13. Weisshaar, R.; Gutsche, B. Formation of acrylamide in heated potato products-Model experiments pointing to asparagine as precursor. Dtsch. Lebensm. Rundsch. 2002, 98, 397-400.

14. Bagdonaite, K.; Derler, K.; Murkovic, M. Determination of acrylamide during roasting of coffee. J. Agric. Food Chem. 2008, 56, 6081-6086. [CrossRef] [PubMed]

15. Stadler, R.H.; Theurillat, V. Acrylamide in coffee. In Coffee: Emerging Health Effects and Disease Prevention; Chu, Y., Ed.; John Wiley \& Sons: Hoboken, NJ, USA, 2012. [CrossRef]

16. Soares, C.M.D.; Alves, R.C.; Oliveira, M.B. Factors affecting acrylamide levels in coffee beverages. In Coffee in Health and Disease Prevention; Preedy, V.R., Ed.; Academic Press: San Diego, CA, USA, 2015; pp. 217-224. [CrossRef]

17. Lantz, I.; Ternite, R.; Wilkens, J.; Hoenicke, K.; Guenther, H.; van der Stegen, G.H. Studies on acrylamide levels in roasting, storage and brewing of coffee. Mol. Nutr. Food Res. 2006, 50, 1039-1046. [CrossRef] [PubMed]

18. Banchero, M.; Pellegrino, G.; Manna, L. Supercritical fluid extraction as a potential mitigation strategy for the reduction of acrylamide level in coffee. J. Food Eng. 2013, 115, 292-297. [CrossRef]

19. Anese, M.; Nicoli, M.C.; Verardo, G.; Munari, M.; Mirolo, G.; Bortolomeazzi, R. Effect of vacuum roasting on acrylamide formation and reduction in coffee beans. Food Chem. 2014, 145, 168-172. [CrossRef] [PubMed]

20. Summa, C.A.; de la Calle, B.; Brohee, M.; Stadler, R.H.; Anklam, E. Impact of the roasting degree of coffee on the in vitro radical scavenging capacity and content of acrylamide. LWT Food Sci. Technol. 2007, 40, 1849-1854. [CrossRef]

21. Senyuva, H.Z.; Gokmen, V. Study of acrylamide in coffee using an improved liquid chromatography mass spectrometry method: Investigation of colour changes and acrylamide formation in coffee during roasting. Food Addit. Contam. 2005, 22, 214-220. [CrossRef]

22. Mojska, H.; Gielecinska, I. Studies of acrylamide level in coffee and coffee substitutes: Influence of raw material and manufacturing conditions. Roczniki Państwowego Zakładu Higieny 2013, 64, 173-181.

23. Granby, K.; Fagt, S. Analysis of acrylamide in coffee and dietary exposure to acrylamide from coffee. Anal. Chim. Acta 2004, 520, 177-182. [CrossRef] 
24. Alves, R.C.; Soares, C.; Casal, S.; Fernandes, J.O.; Oliveira, M.B.P. Acrylamide in espresso coffee: Influence of species, roast degree and brew length. Food Chem. 2010, 119, 929-934. [CrossRef]

25. Rexroth, A. Acrylamide. The new EU regulation 2017/2158. Dtsch. Lebensm. Rundsch. 2018, 114, $142-151$.

26. European Commission. Commission regulation (EU) 2017/2158 of 20 November 2017 establishing mitigation measures and benchmark levels for the reduction of the presence of acrylamide in food. Off. J. EU 2017, L304, 24-44.

27. IARC Working Group on the Evaluation of Carcinogenic Risks to Humans. Furan. IARC Monogr. Eval. Carcinog. Risks Hum. 1995, 63, 393-407. [PubMed]

28. Grosse, Y.; Loomis, D.; Guyton, K.Z.; El, G.F.; Bouvard, V.; Benbrahim-Tallaa, L.; Mattock, H.; Straif, K. Some chemicals that cause tumours of the urinary tract in rodents. Lancet Oncol. 2017, 18, 1003-1004. [CrossRef]

29. IARC Working Group on the Evaluation of Carcinogenic Risks to Humans. Furfuryl alcohol. IARC Monogr. Eval. Carcinog. Risks Hum. 2019, 119, 83-113.

30. Monakhova, Y.B.; Lachenmeier, D.W. The Margin of exposure of 5-hydroxymethylfurfural (HMF) in alcoholic beverages. Environ. Health Toxicol. 2012, 27, e2012016. [CrossRef] [PubMed]

31. NTP. NTP toxicology and carcinogenesis studies of 5-(hydroxymethyl)-2-furfural (CAS No. 67-47-0) in F344/N rats and B6C3F1 mice (gavage studies). Natl. Toxicol. Program Tech. Rep. Ser. 2010, 554, 1-180. [CrossRef]

32. EFSA. Update on furan levels in food from monitoring years 2004-2010 and exposure assessment. EFSA J. 2011, 9, 2347. [CrossRef]

33. Lachenmeier, D.W. Furan in Coffee Products: A Probabilistic Exposure Estimation. In Coffee in Health and Disease Prevention; Preedy, V.R., Ed.; Academic Press: San Diego, CA, USA, 2015; pp. 887-893. [CrossRef]

34. Morehouse, K.M.; Nyman, P.J.; Mcneal, T.P.; Dinovi, M.J.; Perfetti, G.A. Survey of furan in heat processed foods by headspace gas chromatography/mass spectrometry and estimated adult exposure. Food Addit. Contam. 2008, 25, 259-264. [CrossRef]

35. Okaru, A.O.; Lachenmeier, D.W. The food and beverage occurrence of furfuryl alcohol and myrcene-Two emerging potential human carcinogens? Toxics 2017, 5, 9. [CrossRef]

36. Okaru, A.O.; Lachenmeier, D.W. Processing Contaminants: Furfuryl Alcohol. In Encyclopedia of Food Chemistry; Melton, L., Shahidi, F., Varelis, P., Eds.; Elsevier: Amsterdam, The Netherlands, 2019; pp. 543-549. [CrossRef]

37. Albouchi, A.; Russ, J.; Murkovic, M. Parameters affecting the exposure to furfuryl alcohol from coffee. Food Chem. Toxicol. 2018, 118, 473-479. [CrossRef] [PubMed]

38. Albouchi, A.; Murkovic, M. Formation kinetics of furfuryl alcohol in a coffee model system. Food Chem. 2018, 243, 91-95. [CrossRef] [PubMed]

39. Arribas-Lorenzo, G.; Morales, F.J. Estimation of dietary intake of 5-hydroxymethylfurfural and related substances from coffee to Spanish population. Food Chem. Toxicol. 2010, 48, 644-649. [CrossRef] [PubMed]

40. CEN/TC 275. EN 16618:2015. Food Analysis—Determination of Acrylamide in Food by Liquid Chromatography Tandem Mass Spectrometry (LC-ESI-MS/MS); European Committee for Standardization (CEN): Brussels, Belgium, 2015.

41. Waizenegger, J.; Winkler, G.; Kuballa, T.; Ruge, W.; Kersting, M.; Alexy, U.; Lachenmeier, D.W. Analysis and risk assessment of furan in coffee products targeted to adolescents. Food Addit. Contam. Part A 2012, 29, 19-28. [CrossRef] [PubMed]

42. Monakhova, Y.B.; Ruge, W.; Kuballa, T.; Ilse, M.; Winkelmann, O.; Diehl, B.; Thomas, F.; Lachenmeier, D.W. Rapid approach to identify the presence of Arabica and Robusta species in coffee using ${ }^{1} \mathrm{H}$ NMR spectroscopy. Food Chem. 2015, 182, 178-184. [CrossRef] [PubMed]

43. Mueller, U.; Agudo, A.; Carrington, C.; Doerge, D.; Hellenäs, K.E.; Leblanc, J.C.; Rao, M.; Renwick, A.; Slob, W.; Wu, Y. Acrylamide (Addendum). In WHO Food Additives Series 63. Safety Evaluation of Certain Contaminants in Food. Prepared by the Seventy-Second Meeting of the Joint FAO/WHO Expert Committee on Food Additives (JECFA); WHO and FAO: Geneva, Switzerland, 2011; pp. 1-151.

44. JECFA. Furfuryl alcohol and related substances. In Evaluation of Certain Food Additives/Seventy-Sixth Report of the Joint FAO/WHO Expert Committee on Food Additives (JECFA) (WHO Technical Report Series 974); World Health Organization: Geneva, Switzerland, 2012; pp. 67-69. 
45. Carthew, P.; DiNovi, M.; Setzer, R.W. Application of the margin of exposure (MoE) approach to substances in food that are genotoxic and carcinogenic: Example: Furan (CAS No. 110-00-9). Food Chem. Toxicol. 2010, 48, S69-S74. [CrossRef] [PubMed]

46. ISO. ISO 6668:2008. Green Coffee-Preparation of Samples for Use in Sensory Analysis; International Organization for Standardization: Geneva, Switzerland, 2008.

47. EFSA Scientific Committee. Guidance on selected default values to be used by the EFSA Scientific Committee, Scientific Panels and Units in the absence of actual measured data. EFSA J. 2012, 10, 2579. [CrossRef]

48. Bagdonaite, K.; Murkovic, M. Factors affecting the formation of acrylamide in coffee. Czech J. Food Sci. 2004, 22, 22-24. [CrossRef]

49. Kocadagli, T.; Göncuöglu, N.; Hamzalioglu, A.; Gökmen, V. In depth study of acrylamide formation in coffee during roasting: Role of sucrose decomposition and lipid oxidation. Food Funct. 2012, 3, 970-975. [CrossRef]

50. BfR. 5-HMF-Gehalte in Lebensmitteln Sind Nach Derzeitigem Wissenschaftlichen Kenntnisstand Gesundheitlich Unproblematisch. Stellungnahme No 030/2011 des BfR vom 15. Mai 2011 [According to the Current State of Scientific Knowledge 5-HMF Concentrations Occurring in Foods Do Not Give Rise to Safety Concerns. BfR Opinion Nr. 030/2011, 15 May 2011]; Bundesinstitut für Risikobewertung: Berlin, Germany, 2011.

51. Codex Alimentarius. Code of Practice for the Reduction of Acrylamide in Foods (CAC/RCP 67-2009); Joint FAO/WHO Food Standards Programme: Rome, Italy, 2009.

52. IARC Working Group on the Evaluation of Carcinogenic Risks to Humans. Coffee, mate, and very hot beverages. IARC Monogr. Eval. Carcinog. Risks Hum. 2018, 116, 1-501.

53. Loomis, D.; Guyton, K.Z.; Grosse, Y.; Lauby-Secretan, B.; El, G.F.; Bouvard, V.; Benbrahim-Tallaa, L.; Guha, N.; Mattock, H.; Straif, K.; et al. Carcinogenicity of drinking coffee, mate, and very hot beverages. Lancet Oncol. 2016, 17, 877-878. [CrossRef]

54. IARC Working Group on the Evaluation of Carcinogenic Risks to Humans. Coffee. IARC Monogr. Eval. Carcinog. Risks Hum. 1991, 51, 41-206. [PubMed]

(C) 2018 by the authors. Licensee MDPI, Basel, Switzerland. This article is an open access article distributed under the terms and conditions of the Creative Commons Attribution (CC BY) license (http:/ / creativecommons.org/licenses/by/4.0/). 